\title{
Bowed Instruments of the Turkic-Mongol Peoples of Siberia from the Collection of the Russian Museum of Ethnography*
}

\author{
D. A. Bulatova ${ }^{1}$, A. A. Gadjieva ${ }^{2}$ \\ ${ }^{1}$ Russian Institute of Art History, \\ 5, Isaakievskaya sq., St. Petersburg, 190000, Russian Federation \\ ${ }^{2}$ Russian Museum of Ethnography, \\ 4/1, Inzhenernaya str., St. Petersburg, 191186, Russian Federation
}

For citation: Bulatova, Dinara, and Aishat Gadjieva. "Bowed Instruments of the Turkic-Mongol Peoples of Siberia from the Collection of the Russian Museum of Ethnography". Vestnik of Saint Petersburg University. Arts 8, no. 4 (2018): 540-66. https://doi.org/10.21638/spbu15.2018.401

The article is devoted to the study of one of the largest collections of traditional musical instruments - the collection of the Russian Museum of Ethnography. The attention of the authors is drawn to the bowed chordophones of the Siberian Turkic-Mongolian peoples. The most historical and culturally valuable part of this collection is represented by the earliest exemplars collected in the first half of the $20^{\text {th }}$ century: two Tuvinian (Soyots) igils and byzaanchy (the collection of F. Ya.Kon, 1902); Mongolian Khuur (the collection of S. A. Kondratiev, 1923); Tuvinian (Todzhintses) igil (the collection of M. G. Levin, 1926); Khakassian yykh (the collection of L. N. Terentieva, 1939). The history of the acquisition of the bowed chordophones collection of the Siberian Turkic-Mongolian peoples, an ergo-morphological description detailed of the instruments representing the culture of the Tuvinians, Altaians, Khakas, Mongols, Yakuts are given. The studied chordophones belong to the following organological types (according to the musical instruments systematics by E. fon Hornbostel and K. Zaks): the necked lutes (321.32): the necked bowl lutes (321.321: igil, yykh, ikili-topshur), the necked box lutes (321.322: kytiya khyryppa); (321.31): spike box lutes (321.312: khuur, byzaanchy, igil), spike tube lutes (321.313: byzaanchy). The authors draw conclusions about the ergo-morphological features of the instruments: the types of the resonator, the length of the neck, the types of heads and peg boxes, the location of the pegs, the material of the decks and the features of their fixation, the material of the strings, etc.

* The work is carried out under financing by the Ministry of Culture of the Russian Federation and the Government contract N 4584-01-41/06-16 from 09/28/2016. "Bow musical instruments in multiethnic space" (FTP "Culture of Russia /2012-2018/").

(c) Санкт-Петербургский государственный университет, 2018 
Keywords: bowed instruments, chordophones, Turkic-Mongolian peoples of Siberia, igil, byzaanchy, yykh, khuur, ikili-topshur, kytiya khyryppa.

Political events of the second half of the XIX and the beginning of the XXI centuries changed the fate of the Russian Empire / the Soviet Union: all sides of traditional culture were unified and globalized, and therefore the culture of some indigenous peoples and some ethnic and local groups were pushed towards the verge of extinction. However, at the same time, at the turn of the century there appeared an interest in traditional musical culture, and, moreover, some attempts were made to recreate / reconstruct such forgotten musical instruments and revive the extinct traditions of instrumental performance. In these cases, the museum and archival collections, in which the preserved original exemplars of musical instruments that have emerged from everyday life and information about the features of their usage are stored, have become more and more important. The main obstacle was the low level of knowledge of the collections themselves: numerous structural reorganizations of the country's leading museums, confiscation, and a number of transfers from one collection to another led to the depersonalization of museum items and often to their loss. Under such circumstances, the most important tasks were to study the origin of certain collection acquisitions, the attribution of Museum records, and the introduction to the scientific use of research results.

This article is part of the research devoted to the study of the largest collection of traditional musical instruments which is the most representative in St. Petersburg, as well as in Russia, well known not only to a narrow circle of specialists. The collection consists of about 2000 items, including musical instruments of the peoples of Siberia - historical regions of settlement of the Turkic-Mongolian peoples. The authors' attention was drawn to the most valuable specimens of bowed chordophones, which are one of the earliest Museum samples of musical instruments of Tuvans, Altaians, Khakas, Buryats, Mongols collected since the beginning of the twentieth century. The musical instruments under the investigation are often much older than the time of their collection. Being the records of past musical and instrumental traditions, they are of special scientific, historical, and cultural value.

The Russian Museum of Ethnography (RME) was founded in January 1902 as the Ethnographic Department of the Russian Museum of Emperor Alexander III (ED) ${ }^{1}$. The collection of musical instruments of the RME was being created for a century and a half (the collection is older than the Museum) in three ways: about half of it contains the expedition material findings of the Museum staff and correspondents, about a quarter accounts for the acquisition of private collectors and transference from other establishments. The largest was the transfer in 1948, a significant part of the collections of the

${ }^{1}$ In 1918-1934 - Ethnographic Department of the State Russian Museum; in March 1934 was transformed into the Independent State Museum of Ethnography. In 1948, after the transfer of the ethnographic collections of the former Museum of the Peoples of the USSR (Moscow) in funds of SME, it was renamed into the State Museum of Ethnography of the Peoples of the USSR. From 1992 to the present - the Russian Museum of Ethnography (the name was given in connection with the new State status of Russia [Read more: 1]). 
disbanded Museum of the Peoples of the USSR (MP USSR, 1934-1948), which included the collection of Dashkov Ethnographic Museum (DEM, 1867-1923) and its successor, the Central Museum of Ethnology (CME, 1924-1933). The collection of Turkic chordophones provides a significant part of this collection.

The turn of XIX-XX centuries was the period of intensive acquisition of ethnographic collections. At that time, Siberia and the Far East were remote, hard-to-reach regions. Therefore, the head of the Ethnographic Department D. A. Klements, who curated the vast region of Siberia and neighboring areas, attracted local correspondents to gather the collection materials. Among them was the former political prisoner and exiled convict revolutionary, writer, ethnographer and anthropologist F. Y. Cohn. Being in exile in Yakutsk oblast, Irkutsk, and Minusinsk he was actively engaged in scientific findings. At the beginning of the XX century, at the invitation of the East Siberian Division of the Imperial Russian Geographical Society (ESD IRGS), F.Y.Cohn participated in an expedition to study the indigenous population of Tuva, when they had been under the control of the Manchurian dynasty [2]. F. Y. Cohn collected ethnographic and anthropological collections of four museums: the Minusinsk local history [3], Irkutsk Museum of the ESD IRGS, the Anthropological Museum of Moscow State University (AM), [I] and the ED [II]. In June - December 1902 research and collection of materials was carried out in the Western and Central regions of Tuva. After a break, which was spent on processing of the received data and on getting ready for further route from March to August 1903 F. Y. Cohn explored the southern and Eastern regions [4] and managed to gather the largest, more than 1,500 items, systematic collection covering all aspects of Tuvan traditional culture [5].

The Fund ED received 5 shamanic drums with mallets from different parts of Tuva [II, 1. 41] and 15 musical instruments (including 5 Buddhist [II, l. 45]), half of which were stringed ones ( 2 chadagans ${ }^{2}, 3$ topshulurs, 2 igils and 1 byzaanchy [II, 1. 48-49]). Unfortunately, F. Y. Cohn was unable to register the items of collection he had completed. After the exile, he was forbidden to enter the capital, and since 1904 Cohn's major was connected with social and political activity. Nevertheless, the field inventories and labels the collector provided exhibits with, allowed Ts. Zhamtsarano to avoid serious mistakes in Cohn's materials.

The Fund AM received 2 shamanic drums with mallets from different parts of Tuva and 14 musical instruments (including 4 Buddhist [III; I], string - 2 (byzaanchy and topshulur). In 1932, AM's ethnographic collections were transferred to the Central Museum Ethnology (CME) [IV], which was transformed into the Museum of the peoples of the USSR (MP USSR) in 1934, and in 1948, due to the dissolution of MP USSR, the State Museum of Ethnography part of the collection was lost or transferred to other museums. Until now, we have not managed to find stringed instruments from the collection of AM's; therefore a rare description of string spike box lutes of an undoubted interest:

“Collection № 17. Registration collection list № 17 of the Ethnological Department of the Museum of Anthropology of Moscow State University. It appeared in 1903 from F. Cohn. It was collected from the uryankhai. The collection comprises 134 numbers and 142 ethnographic items"3.

${ }^{2}$ Names of the collection are given according to the inventory list.

3 Apparently, not all packages came at the same time: the inventory was continued and its numbers reach 229 . 
17/134. Buzanche. Stringed bow instrument. Consists of a wooden box of a trapezoidal shape ${ }^{4}$, through which a long fretboard with 4 long pegs to which strings of horse hair are attached is fed. String sare stretched without touching the fretboard. At the bottom of the neck, there is afretted pattern in the form of multiplication sign. Up the instrument deck, a cross-section and a crosswise hole below are seen. The end of the neck is visible through the hole at the bottom of the instrument, from which a small strap sticks out. Length $-90 \mathrm{~cm}$, the bow is missing. The strings are broken» $[\mathrm{VI}]$.

F. Y. Cohn's collection might have included one more Tuvan bowed chordophone which is mentioned in the Typological Catalogue of soyots-uriyangkhai, compiled by B. A. Kuftin. There is a description of three musical instruments from the collection of F. Y. Cohn, two of which (Temir-Komyz and Byzaanchy) were not registered in the collection inventory:

"190. Buzanche (topshulur)5. A stringed bow instrument like a Chinese one [illigib.] consists of a wooden cylinder, one hole of which is tighten with a bubble or leather. Through the cylinder wall there stretches a long wooden rod, the neck is $70 \mathrm{~cm}$ with four long pegs, which attach strings from a bundle of horsehair each. Strings stretch further without touching the fretboard, no frets here. The bow is wooden, which has two tied to each other strings from a bundle of horsehair. The bow is fed between the strings so that it can touch their outer and facing sides. While playing, one can put the instrument on the knee; by the left hand nails or by special reed thimbles you can press the strings, raising the sound. A piece of larch resin, used instead of rosin to rub the strings and bow. Usually a small piece of this resin is attached to the base of the fretboard" [III, 1. 73-74].

In 1926 as a part of complex expedition under the leadership of V.Bunak the post-graduate student of Anthropological Institute M. G. Levin made his first trip to Tuva-Todzhinets. The collector carefully fixed the traditional terminology, data on the existing subjects, and used the received information at registration of the delivery. The number of purchased items -2 shaman tambourines and 4 musical instruments, three of which are spike box lutes with a trapezoidal enclosure of identical design (two plucked and one stringed). The collection was obtained by AM. Then in 1932 it was transferred to the CME, and in 1948, after the MP USSR being disbanded they appeared in SME. The chain of transfers led to the depersonalization of the collection. Based on the descriptions carried out by the collector, they managed to be attributed:

“Collection № 1. From the Tannu-Tuva antropologo-ethnographic expedition of 1926. Superviser of the expedition prof. V.V.Bunak. Collector of the ethnographic expedition the graduate student of Anthropological institute M.G.Levin, November, 1926. It is transferred to the Anthropological Museum by the commission on studying of the Mongolian and Tannu-Tuva Republics at Council of People's Commissars USSR, and Tannu-Tuva People's Republic (former Uryankhay region) was registered by M. G. Levin.

1/16a [RME, Inv. № 8761-8415ab*] ${ }^{6}$.

A string bowed musical instrument "ihil". The deck "hardzha" of a trapezoidal shape consists of a wooden frame tightened by musk deer skin. At the bottom of the deck two round holes

4 Topshulur is also a spike box lute with trapezoidal body [V, 1.34, No. 61/106].

${ }^{5}$ In the F. Y.Cohn's List Byzaanchy and Topshulur are two different instruments (ibid.). Topshulur"straggler" exhibit — the 61st collection, see above).

"Hereinafter the sign " "*" indicates the attribution of the authors.

7 From the description it follows that under the "deck" by M. G. Levin meant the body of the instrument.

${ }^{8}$ Ethnic terms and names of the locality are given in the collector's transcription. 
and a big fragmentary, and a round one on the sidewalls. The fretboard (Syby) long tetrahedral, passes through the deck, forming a sharp ledge on the lower wall of the deck. The expanded top end of the fretboard, from the lower surface is hollowed in the shape of a rectangular box ${ }^{9}$, decorated on the sidewalls by the carved ornament of curves, on the top and lower surface ${ }^{10}$ with straight lines. Two pegs "hula" are arranged horizontally (perpendicularly to thesidewall of the fretboard). Two strings "hyl" of black horsehair: one string of 12 hairs, the other -4 . At the bottom, the string sare tied to two ends of the cord from veins strengthened on the lower ledge of the fretboard. Total length -87 , the deck's length -18 , the top width of the deck -11 , the lower width of the deck -14 , the hight of the deck $-6 \mathrm{~cm}$. Tandzhik Kol-Sumo, the settlement on the river Iy, 5 versts from the small settlement of Petrov. The instruments acquired from the Tuvinian. Ihil made by the seller himself according to the sample which was seen at Tuvinians neighbors ${ }^{11}$. Tuning pegs are broken. The bridge under the strings "tekpe" is missing too.

$1 / 16 \mathrm{~b}$.

The bow "Chadzha" - beam from willow with strained strings of black horsehair in black color (13 hairs). Length between the ends 46 , height $12 \mathrm{~cm}^{12}$.

Inventory book of collections collected by the expedition of the Mongolian Commission of the Council of people's Commissars in Tannu-Tuva Republic" [VI, 1. 42].

After graduating from the post graduate course, M. G. Levin regularly went on expeditions to Altai, Tuva and other regions of Siberia, but brought only plucked instruments. Similar picture is shown by the collections of other researchers.

In 1936, SME created a special structural division - the Folk-music section (FMS), employees who became members of the Leningrad ethnographic ensemble under the leadership of B.P. Salmont. One of the activities of the section was the expedition-gathering work with the fixation of samples of folklore of the peoples of the USSR. In 1936 the ensemble visited the Oyrot region, from where the FMS employees brought clothing, the collections of drawings and photographs of musicians and professionals of musical instruments, 1,200 handwritten recordings of folklore texts (Altai and Russian), recordings on 115 phonographic rollers (including purchased for the Museum instruments), records of traditional terminology (in Altai, with translation into Russian), relating to two areas: 1. parts of musical instruments and 2. techniques of playing the musical instruments.

In the collection № 5896 there were 47 items, reflecting the process of making topshur and homus (idiophone) and some ready-made instruments. From 47 numbers only 2 samples are bowed ones, therefore it is possible to see smaller percentage of bowed instruments in comparison with the plucked ones, idiophones and aerophones. The same is seen in the recordings of phonographic rollers. The rollers №№ 8,9 and 12 were recorded by the musician, multi-instrumentalist, I. Saraskina: № $8^{13}$ : № $8-$ by ekili, № $9-$ by komys and abyrga; roller № 12 - by shour; roller № 15 - by ekili and topshur (Kadokawa and Chekirov ${ }^{14}$ ); roller № 28 - by topshur and ekili (Kerekov Ad[esh], from the village of Ykonor; a 48 years old, collective farmer, non-partisan [illegible] [VI].

9 The back side and a circled box are meant here.

10 This is a view of the face and back sides.

11 In MP USSR made a PostScript: "КП 34753a" — the incoming number of the register book.

12 In MP USSR made a PostScript: "КП 34753b".

13 From Sabashkin the items showing different stages of production of a homus are acquired (collection 5896).

${ }^{14}$ In the inventory of collection 5896 is reported: "Chekirov 70 years, is from the Ust-Kansky aimag of Beloanuysky village administration: the item of Beloanuy. In Beshpalmir he lives 30 years, works as a watch- 
In the archives [VII] there are lists of collections assembled by the ensemble in Buryat-Mongolia in the period between the second half of the 1920s-the beginning of the 1930s. Most of these materials were transferred to various institutions - to the Archive and the Regional Museum of Verkhne-Udinsk (in July 1934 renamed into Ulan-Ude), CME, etc., which are marked in the "notes" field. However, the information about the transfer of musical instruments and some other records are missing. Among the exhibits, there are three bowed string instruments, whose fate has not been clarified.

\section{“229. Khuuchir (Mus. instr.)}

241. Archaic Mongolo-Buryatquardavy khuur (violin)

242. Khuur with a horse head on the neck [VII, 1. 35-36 ${ }^{15}$. This is followed by a detailed description of the Khuuchir [VII, 1. 43-44]. B. P. Salmont needed measurements in detail for making copies and reconstruction of the instrument.

The Buryat Fund of RME possesses three last samples collected in 1960 and $1977^{16}$; but the earliest ones nowadays are considered to be two stringed instruments one of which is a spike box lute (RME, inv. № 8761-7620 ${ }^{17}$. However, it is not yet possible to find documents that would help to verify the attribution of the monuments, and the question of their origin remains open.

Few Mongolian, Chinese, Japanese and Korean bowed instruments in the Museum's collections are available (tube and box spike lutes, Chinese Citra la-qin), and their descriptions are preserved. According to the People's Commisariat of Education (Narkompross) the collection of these peoples did not fall into line with the course of RME and in the 1930s they were gradually transferred to other institutions. Only a few impersonal and misidentified items were left. Among them was Mongolian khuur without collector's number which is enlisted in the inventory book (RME, inv. № 6957-16a6) Thorough the examination of some archival documents, it was possible to identify the exhibit [VIII] in question. It turned out to be one of the instruments collected by P. K. Kozlov. S. A. Kondratyev, a participant of the Mongolian-Tibetan expedition ([7;8]) was personally summoned to study the item of Mongolian musical culture. But unfortunately he was given too little time to study it: he had to take part directly in archeological investigation. However, Sergey Kondratyev managed to do a lot.

"The conditions of my work in Urga for... three months were the most favorable. The Scientific Committee under the Mongolian Government had long been looking for a musician to consolidate the rich material available in Mongolia, and therefore willingly met my expectation. The Committee member Ts. Zh. Zhamtsarano rendered the most active assistance; the hospitable house of that eminent public figure of Mongolia was the place where I did my job. There were invited the most prominent musicians of Urga, as well as music admirers of different professions

man in the collective farm now". The findings obtained from him demonstrate different stages of production of musical instruments, among them - topshur, homus and some others.

15 Perhaps, these 2 khuurs were sold by B.P. Salmont to the Museum of Musical Instruments in 1935. (MM, inv. № 16516/1693 and 16516/1694 [6, № 333; 3]

16 Two traditional khuuchir (RME, inv. № 7275-46ab; inv. № 8699-1ab) and khuur of a soprano representing the local version of the European violin (RME, inv. № 7275-46ab, collecting L. G. Lelchuk 1960).

17 Three-stringed box-shaped spike box lute, identical to Japanese kokyu (see below), but unlike the last, the case is made of a pine (it was made of valuable sorts of a wood). Inside the body there are Chinese hieroglyphs in black paint. 
and positions: ministers, militiamen, sovereign princes, butchers, schoolchildren, princesses, soldiers. Some natives of local Western and Eastern areas came to visit Ugra, therefore I had an opportunity to get acquainted, though incompletely, with music of all Mongolia, without leaving Urga. Actually, I studied vocal music, and did not neglect instrumental one. I described all the most useful and characteristic Mongolian instruments, which were obtained by the expedition $\langle\ldots\rangle$.

Of all the instruments used in Mongolia, khuur deserves the greatest attention byits noble as well as a bit dull sounding and by its significance as the only national instrument. Khuur, both in tone and in design resembles a small cello, with the only difference in that khuur has two strings and the second stand at the top of the fretboard separates it from the strings at a considerable distance, so that the fingers only touch them, but do not not press them to the wood. This circumstance sardiniae sonority of khuur, making it weak, but gives it a delicate, misty touch. The khuur fretboard always ends with a picturesquely carved horse head - the emblem of Mongolia, and the instrument itself is classified as res sacra. I had to listen to musicians who were significantly fluent at playing the khuur. Other instruments are yataga, schanz (plucked), khochir (bowed) and the flute which are definitely of Chinese origin. According to Taneev ensemble playing by these instruments is often a "counterpoint in unison", and therefore produces a painful impression on those who are spoiled by harmony $<\ldots$.

140 chants recorded by me ethnically are divided into: Mongolian -103 , Buryat -15 , Tibetan (religious) -7 , Tangut -2 , tsaydam -1 , Chinese -6 , Korean -6 , and in total -140 . Of 103 originally Mongolian melodies, the predominance falls on those from the Eastern Part of Inner Mongolia.

The music of Western Mongolia is studied much less, and the southern provinces (Ordos, Alashan) have not been touched upon yet. Filling these gaps is my next task" [8, p. 174-5].

It is stated nowadays that Kozlov's expedition brought no fewer than 10 musical instruments, among them there are two Mongolian khuurs and two Chinese khuuchirs ${ }^{18}$, but the legendas of exhibits have not been found yet, and research still should be continued.

The region of Siberia, where different peoples: Samoyed, Finno-Ugric, Tungus-Manchurian, Turkic have been living since ancient times - has a developed culture of performing on bowed chordophones [see: 9]. The collection of the Russian ethnographic Museum contains stringed instruments of the Turkic: Tuvan (Soyot, Uriyangkhai, Todzhintsy), Altaians, Khakas (Kachin), Yakut; Mongolian peoples: the Buryats, Mongols. The collection of instruments refers to different times (from the turn of XIX-XX centuries to the beginning of the XXI century). According to the systematics of E. Hornbostel and K. Sachs the following types of chordophones are presented: 321.32 necked lutes, characterized by the presence of neck and the resonator housing; and 321.31 spike lutes, where "grip-the neck is fed through the resonator body diameter" [10, p. 252]. The instruments of the first type comprise Tuvan igil, Altai "ikili-topshur", Khakass yykh, which combine the presence of

18 One khuuchir and a khuur from Kozlov’s collection (№ 9 and 10 according to the collector’s list) were transferred to the Museum of Anthropology and Ethnology in 1938 (list № 2 to the act of September 27). 
the neck and body, hollowed out of a single piece of wood, and two hair strings. The face body of the instrument is covered with leather.

Spike lutes (box and tube) in the collection of the RME is presented by Tuvan (4-stringed, byzaanchy, an exemplar of the 2-stringed igil), Buryat (4-stringed khuuchir: RME, inv. № 7275-45 ${ }^{19}$ and 8699-1 ${ }^{20}$ ), Mongolian (2-stringed khuur) instruments. They consist of a long neck with a spike carved from a single piece of wood. The spike passes through a body of cylindrical or faceted shape close to the face of the body, tightened by skin.

The collection has the original exemplar of Yakut khyryppa ${ }^{21}$ (RME, inv. № 9915$72^{22}$ ), which looks like a European violin.

RME, inv. № 633-38/ab.

Igil. Tuvinians (Soyots ${ }^{23}$ ).

Late $19^{\text {th }}$ century. Area Ottuktash-Bulun, Basin of Upper Yenisei, Northern Mongolia. 1902. Collecting of F. Y. Cohn (fig. 1, 2).

Wood, leather, horse hair

a) Instrument is hollowed from solid piece of wood. Body of oval form with protruding leg narrowing from top to bottom. Cavity tightened with skin, which from back is pulled together with leather thongs.

Hole passes through leg. The tailpiece thong is put on leg by a loop, its ends are fed through a leg hole from the back and removed outside. Leather thongs of tailpiece of different length $-26,0$ and $18,0 \mathrm{~cm}$.

Sound hole rectangular cut is on the leather deck. Bridge (length of $3,5 \mathrm{~cm}$, height of $0,1 \mathrm{~cm}$, width of $0,5 \mathrm{~cm}$ ) with two pits (width of $0,5 \mathrm{~cm}$, depth of $0,2 \mathrm{~cm}$ ) for strings was found inside the body.

Backside of body is hewed with a lot of roughness and chips. Back is pointed in the center.

Neck of a rounded shape, hewed smoothly and polished.

Peg box is hollowed from back. Two face holes drilled for strings.

Neck with head and handle of tuning peg are impregnated with drying oil.

Pegs of predominantly cylindrical shape extended in the direction of the handle (length of 15,0 and 15,5 cm, the diameter of the handles 1,9 and 1,8 cm). There are splits in pegs for fastening strings. Black horsehair strings, one end is fastened to split, other ends are tied to tailpiece.

Total length $-109,0 \mathrm{~cm}$

Length of body $-34,0 \mathrm{~cm}$

Width of body $-15,5 \mathrm{~cm}$

Height of body $-6,0 \mathrm{~cm}$

\footnotetext{
19 Collection L. G. Lelchuk, 1960.

20 Acquired through the purchasing Commission from Dorzhiev, J. D. 1977.

21 The name "khyryppa" is a Yakut variant of the Russian word "skripka" ("violin").

22 Collection L. G. Lelchuk, 1978.

${ }^{23}$ The names and terms used in inventory inventories of RME are designated by italics.
} 

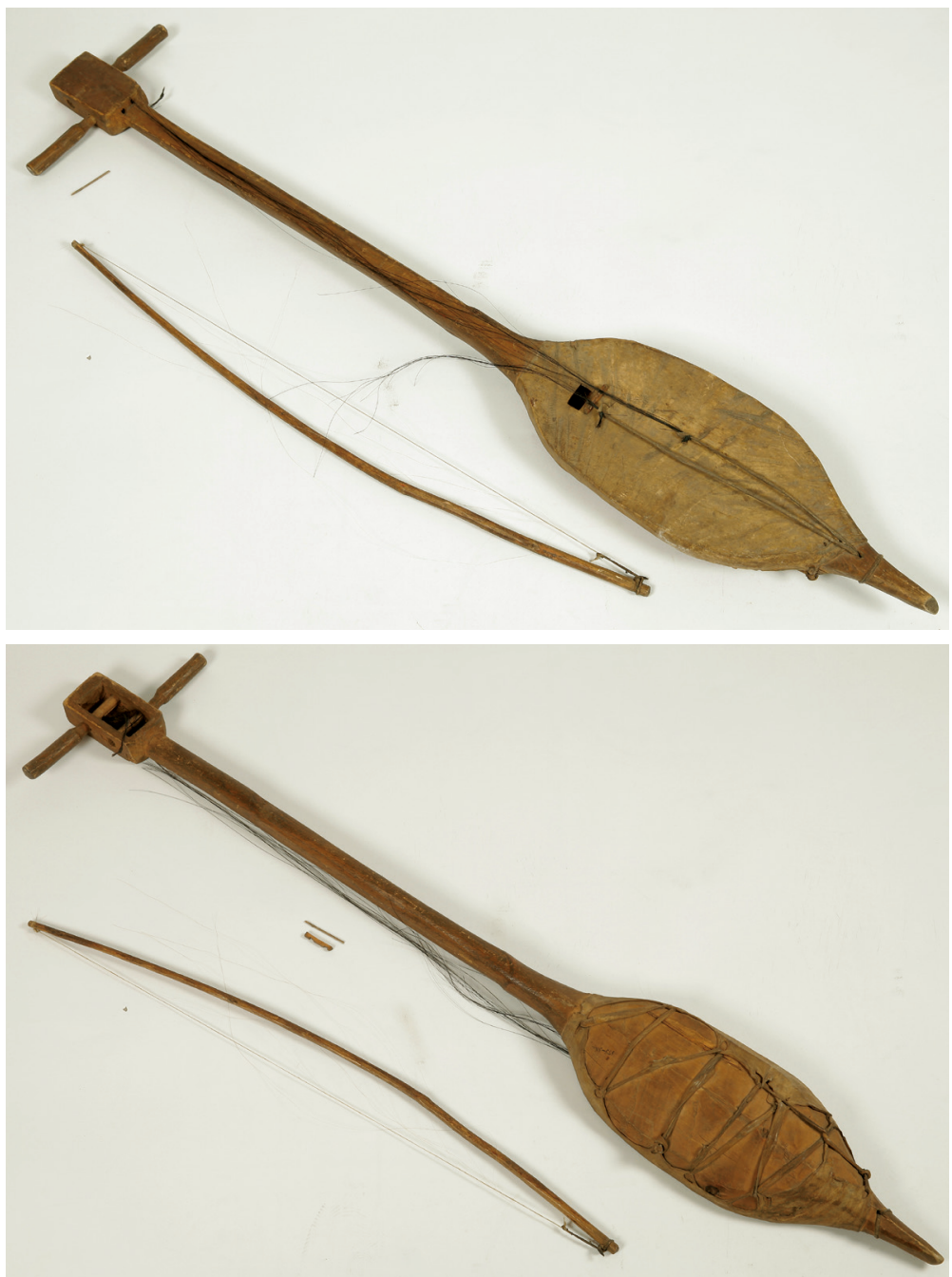

Fig. 1, 2. Igil. Tuvinians (Soyots). RME, inv. № 633-38/ab

\section{b) Bow}

Rod made of wood (branch). Its inside hewed directly, outside is round. At the edges - cuts for fastening hair. Bunch of light horsehair of redish shade is fastened to leather thong with release of $4,5 \mathrm{~cm}$ from holding bow.

Total length $-70,0 \mathrm{~cm}$

Rod $-71,0 \mathrm{~cm}$

Curve depth $-4,5 \mathrm{~cm}$ 
RME, inv. № 633-37/abcd.

Igil. Tuvinians (Soyots).

Late $19^{\text {th }}$ century. Area Talyen, Basin of Upper Yenisei, Northern Mongolia. 1902.

Collecting of F. Y. Cohn (fig. 3, 4).

Wood, leather, horse hair, tendinous rope, pitch

a) Body with a bulge in the lower part and neck with head are hollowed from a solid piece of wood. Extended body of round shape, cavity is hollowed from face and tightened by a leather membrane edges fastened from back by a tendinous rope. Bulge - in the lower part of the body. Bowed face ends of tendinous rope are fret through two holes in the bulge from back to face; strings fastened to their loose ends. Existing strings from black horsehair torn off. Resonator hole of rounded shape, diameter of $1 \mathrm{x} 1,5 \mathrm{~cm}$, on membrane face.

Neck flat from face and cut from back. Nut with scrapes from strings cut at upper part of neck and basis of head.

Peg box is cut out from back in the form of case with sliding lid.

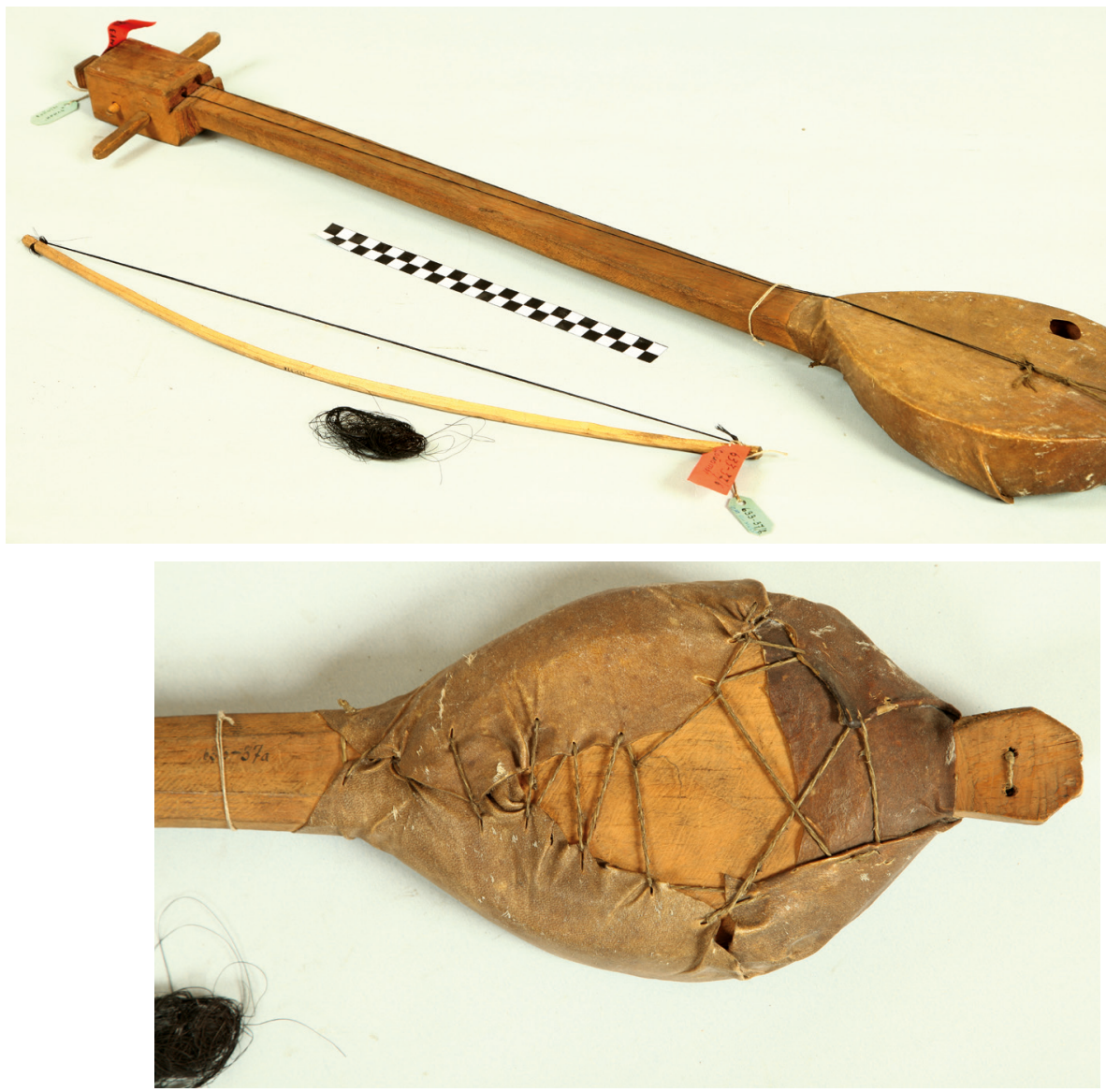

Fig. 3, 4. Igil. Tuvinians (Soyots). RME, inv. No. 633-37/abcd 


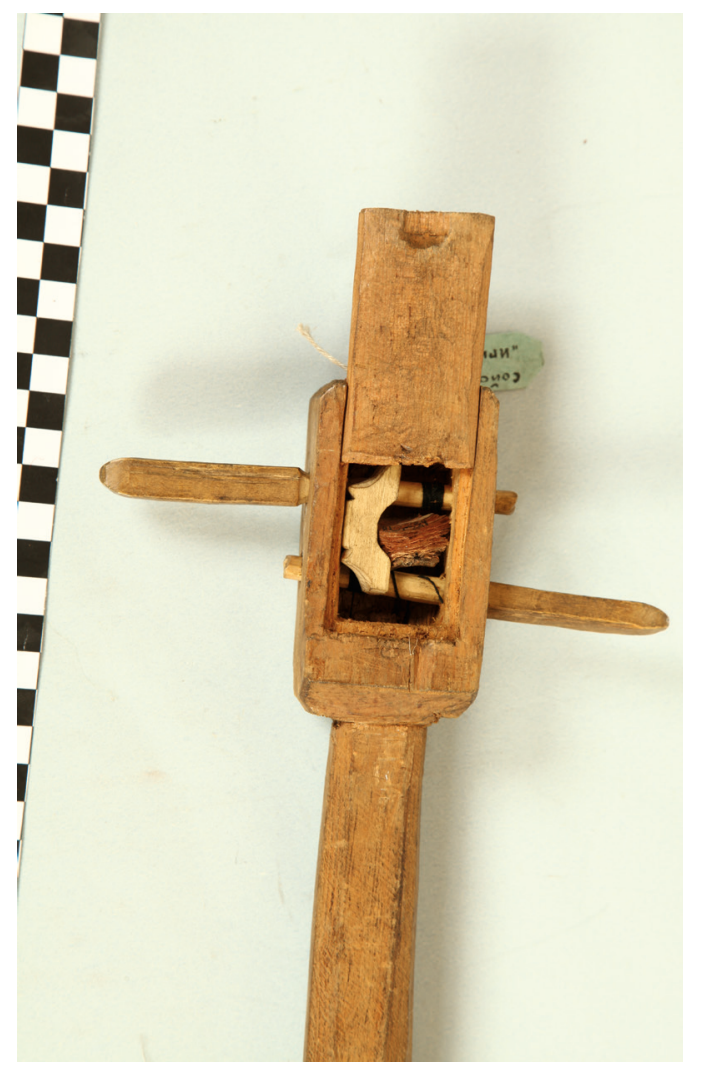

Fig. 5. Igil. Tuvinians (Soyots). RME, inv. No. 633-37/ abcd
Tuning pegs with cylinder heads and rectangular handles with pointed end are inserted into tuning peg box from two sides. Heads of tuning peg with split at length to fasten strings.

In the lower part of tuning box, two face holes for strings are drilled.

Bridge (c) under strings, triangular in section with round split of 0,7 hight and two splits for strings at the top. Bridge is stored in tuning peg box. Here piece of bark and rosin (d) are hidden (fig. 5).

$$
\begin{aligned}
& \text { Total length }-87,7 \mathrm{~cm} \\
& \text { Length of body }-22,7 \mathrm{~cm} \\
& \text { Width of body }-14,0 \mathrm{~cm} \\
& \text { Hight of body }-5,0 \mathrm{~cm}
\end{aligned}
$$

b) Bow is made of wood (cleaned branch) cut at sides. At edges cuts for fastening hair. Hair is new (restoration 1950s)

$$
\begin{aligned}
& \text { Length }-53,0 \mathrm{~cm} \\
& \text { Length of rod }-54,0 \mathrm{~cm} \\
& \text { Depth of curve }-4,5 \mathrm{~cm}
\end{aligned}
$$

RME, inv. № 6210-15/ab.

Yykh (?). Khakas (Kachinets).

1920s - 1930s. Ust-Abakan district (collective farm Komintern),

Khakass autonomous region, Krasnoyarsk Krai. 1939.

Collecting of L.N. Terentyeva. Acquired from I. A. Inkhizhekov (fig. 6, 7).

Wood, leather, horse hair, metal

a) Body of instrument oval with bulge in the lower part, straight neck and head cut roughly from uniform piece of wood. Cavity of body hewed from above and tightened by leather. Triangle wedge cut out in the lower part of leather membrane. Bulge of body fed through the hole, cut-out wedge pulled back and fixed by nail. Edges of membrane unbent and nailed by thin metal brackets on lateral sides of body. Two resonator holes are on backside of body: round in center and square to the right of performer.

Through hole burnt out on bulge. Tailpiece-thong fed through hole. Horsehair strings tied to tailpiece by one end. They are fed through hole to backside of tuning peg box into its bowed split (some scraps of black horsehair remained). 

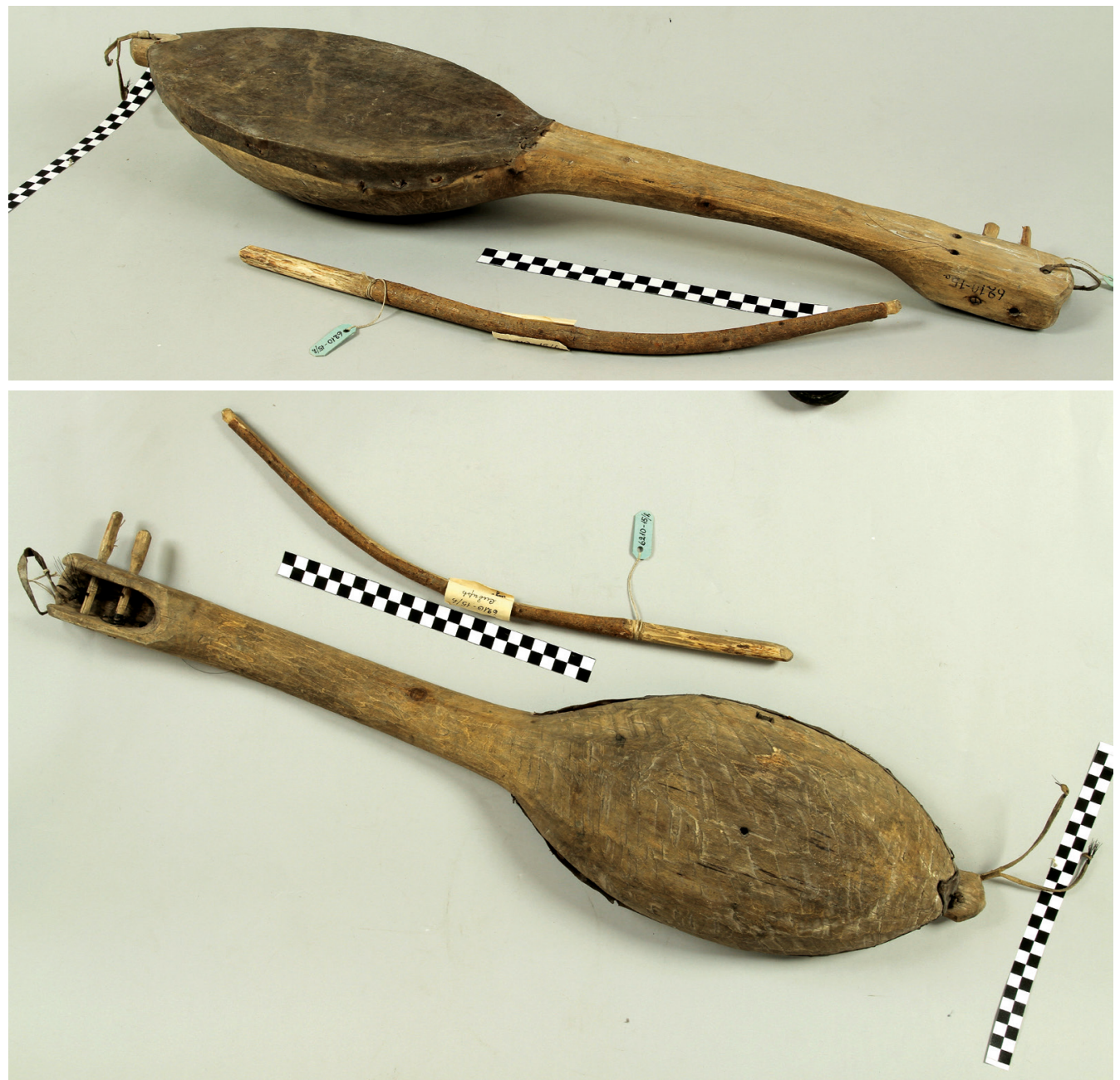

Fig. 6, 7. Yykh. Khakas (Kachinets). RME, inv. № 6210-15/ab

Neck narrows up and by the head it widens and transforms smoothly into head itself, Cavity hewed from backside of head. Head is open at top. Two holes for strings burnt out under small angle in lower part of head from backside to face. A pair of tuning peg holes burnt out on lateral sides.

Tuning pegs of mainly cylinder shape with spade formed handles and splits for strings inserted on right side of performer, and fed through both sides of tuning peg box. Thong for hanging instrument fed through drilled hole in upper part of tuning peg box.

Total length with bulge in the lower part $-80,0 \mathrm{~cm}$ (length of bulge $4,0 \mathrm{~cm}$ )

Body width $-19,0 \mathrm{~cm}$

Body height $-9,2 \mathrm{~cm}$

Neck length with head $-40,5 \mathrm{~cm}$

Body length $-35,5 \mathrm{~cm}$ 
b) Bow - from massive wooden branch. Bark cleaned on handle and inside of rod. Grooves for fastening of horsehair hewed at top of handle and on upper end of rod.

Length $-50,0 \mathrm{~cm}$

Length of rod with handle and bulge for fastening hair $-52,0 \mathrm{~cm}(38,0+12,5+1,5 \mathrm{~cm})$.

Length of the working part of bow $-36,0 \mathrm{~cm}$

RME, inv. № 12424-41/1, 2.

Ikili-topshur ${ }^{24}$. Altaians (Altai-Kizhi).

Late $20^{\text {th }}$ - early $21^{\text {st }}$ century. Gorno-Altaysk, Altai Republic. 2006.

Collecting of S. V. Romanova and M.N. Kochukova (fig. 8).

Wood, leather, metal, fishing line, varnish

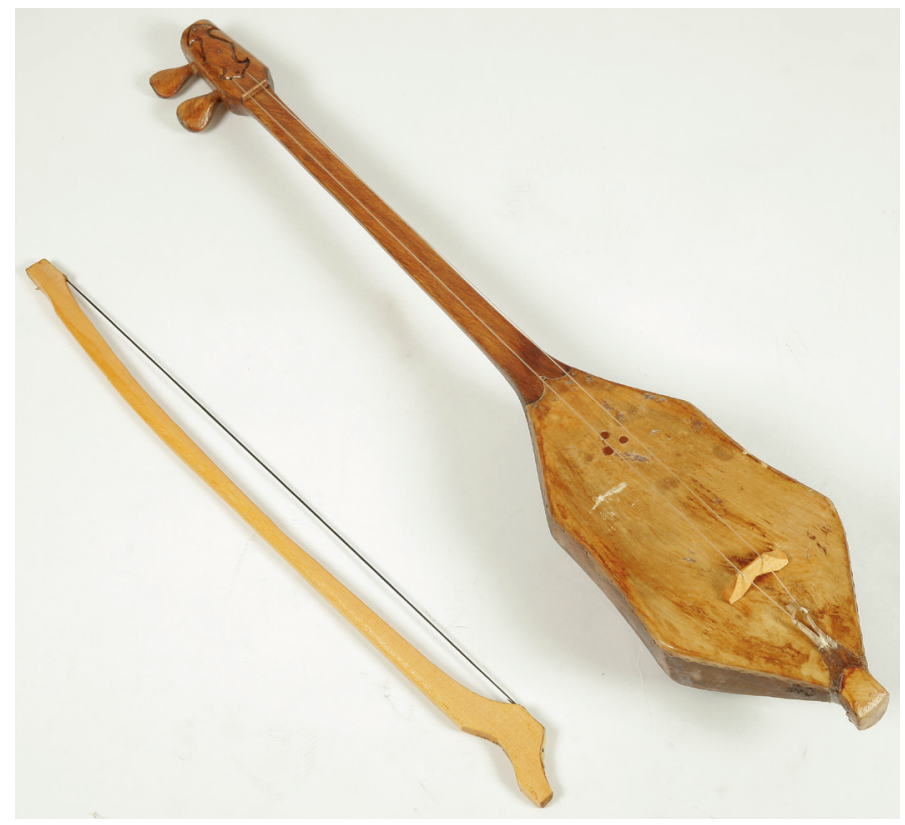

Fig. 8. Ikili-topshur. Altaians (Altai-Kizhi). RME, inv. № 12424-41/1, 2

1) Body with bulge in lower part, neck and head hewed from uniform piece of wood. Body smoothly passes into neck and then into head. Body of drop shape (hexahedron extended at top) hewed from face and covered with leather membrane. Edges of leather unbent, stuck to sidewalls and to bulge in lower part of body by nails. Three round resonators in form of triangle on leather at top in narrow part. Neck flat on face, round from back. At basis of head, wooden nut is of triangular section. Two splits under strings made at top in narrow part.

${ }^{24}$ By the name of the instrument the master sought to emphasize the possibility of its application as stringed or plucked at the same time that reflects the traditional manner of playing music on the hordophones in the region of Siberia and the Far East. Not accidentally many plucked and stringed hordophones of Tuvinians and Altaians possessed by the RME are almost identical in the morphology. 
Form of head close to rectangular with round edges. Face decorated with carved geometrical ornament.

Peg box hollowed from back of head. Two through holes for strings hewed into face of peg box. Tuning pegs cut out from lateral face head. Splits of slightly pointed form with handles inserted from right of performer. Through holes for strings hewed closer to center.

Triangle wooden bridge with triangle split in lower part, and slanted top angles. At top of bridge two grooves for strings fed.

Tailpiece, piece of skin with split put on bulge in lower part of instrument. Free strip cut into two thongs for fastening strings. Two strings from fishing line in lower part tied to tailpiece thongs fed through bridge, nut then further through head holes into tuning pegs throughout holes of tuning pegs and bowed.

Instrument body, including tailpiece, soundboard, tuning pegs varnished.

Instrument: no traces of existence.

Total length $-86,0 \mathrm{~cm}$

Maximum width of body $-16,0 \mathrm{~cm}$

Height of body $-10,0 \mathrm{~cm}$

2) Bow

Rod in form of slightly curved arch and handle cut out from one plate. Black horsehair fixed by straps of leather stuck to ends of rod. Rod varnished.

Length $-62,0 \mathrm{~cm}$

Width of curve $-4,7 \mathrm{~cm}$

RME, inv. № 633-36/ab.

Byzaanchy ("buzanche"). Tuvinians (Soyots).

Late $19^{\text {th }}$ century. Basin of Upper Yenisei, Northern Mongolia. 1902.

Collecting of F. Y.Cohn (fig. 9, 10).

Wood, leather, horse hair, metal: brass

a) The instrument represents tube spike lute. Cylinder body is made of solid wood. It is covered with leather (snake?). Wooden plate is inserted and glued from back side of body (ordinary restoration?).

The body is covered with carving (except the lower part). Ornament geometrical rectangle, rhomboid, triangle, and with crossed lines.

Spike and neck are cut out from solid piece of wood, head is not shaped. Four flowers, diameter of 3,0 cm are cut out from the same piece of wood: three eight-petal at the top, and six-petal in lower part. Tuning peg hole is made in the center of each flower. The fifth flower at the top of neck - with double rosette, diameter of $2,5 \mathrm{~cm}$. Tuning pegs are inserted from backside.

Neck from face is decorated with carving. Ornament is geometrical.

Bulge of spike is drilled with through hole. Tailpiece out of two leather thongs is put on bulge and fed through the hole.

Strings of horsehair are fastened to loose ends of thongs. They are fed through brass ring, diameter of $0,8 \mathrm{~cm}$, tied to neck with loop from tendinous rope (fig. 11). Upper end of strings are fastened to tuning pegs. 

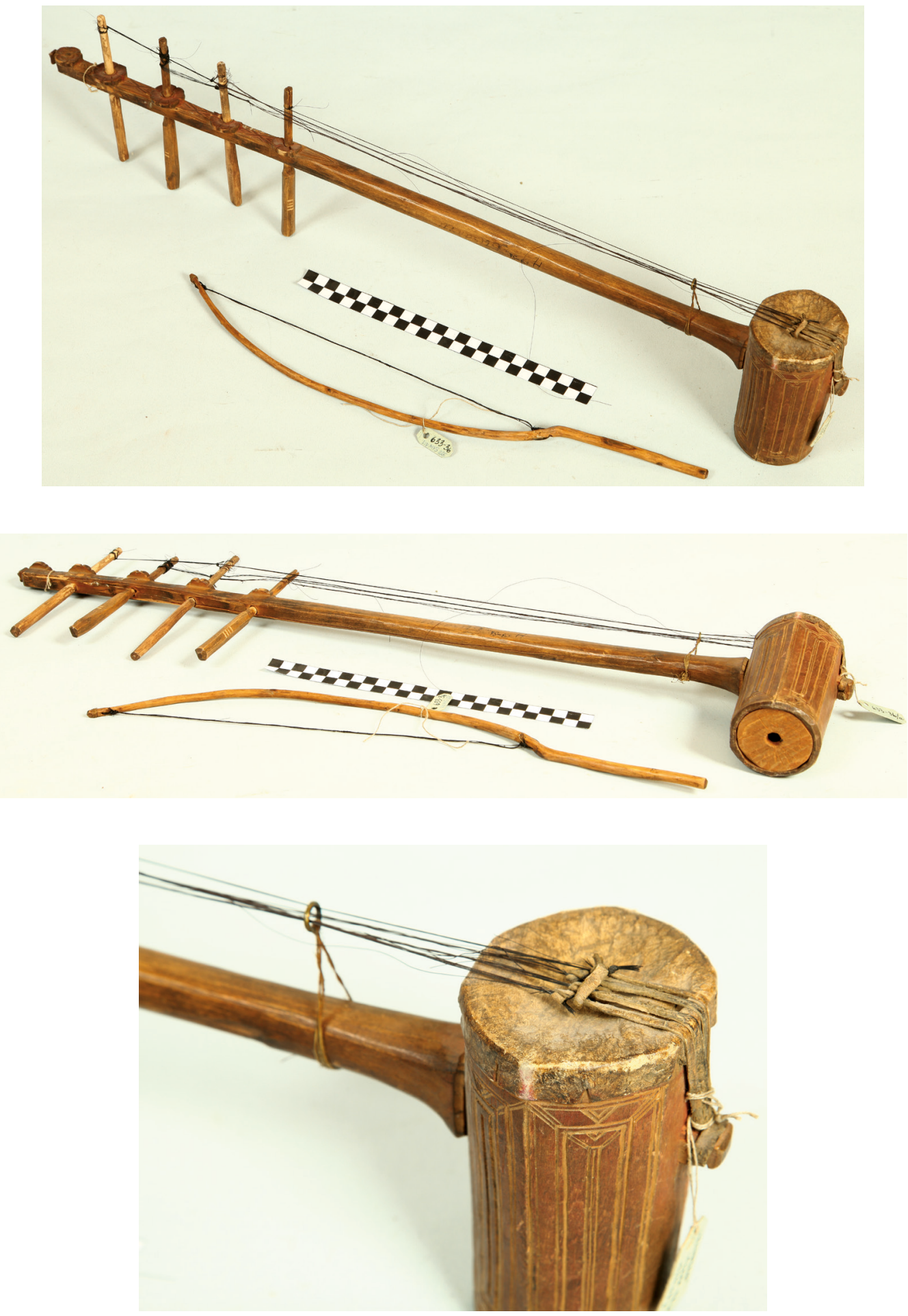

Fig. 9, 10, 11. Byzaanchy (“buzanche”). Tuvinians (Soyots). RME, inv. № 633-36/ab 
Total length of instrument $-73,0 \mathrm{~cm}$

Width of neck $-2,3 \times 1,5 \mathrm{~cm}$

Diameter of face body $7,0 \mathrm{~cm}$, from backside $-6,0-6,5 \mathrm{~cm}$

Length of body $-13,0 \mathrm{~cm}$

b) Bow

Rod of curved cut branch. Two holes for fastening horsehair are hewed in bow ends let alone handle. Upper end of bow is fastened by tendinous thread (ordinary restoration).

Length of bow with handle $-46,0 \mathrm{~cm}$

Length of rod with handle $-48,0 \mathrm{~cm}$

Length of handle $-12,0 \mathrm{~cm}$

Depth of curve $-4,5 \mathrm{~cm}$

RME, inv. № 10064-68/ab.

Byzaanchy. Tuvinians.

1979. State farm Kara-Khol, Bai-Tayginsky area, the Tuva ASSR.

Maker - B. L. Kuzhuget. Collector - N. G. Aloyeva (fig. 12).

Wood: larch, willow, goat leather, leatherette, horse hair, paper, metal, twisted rope

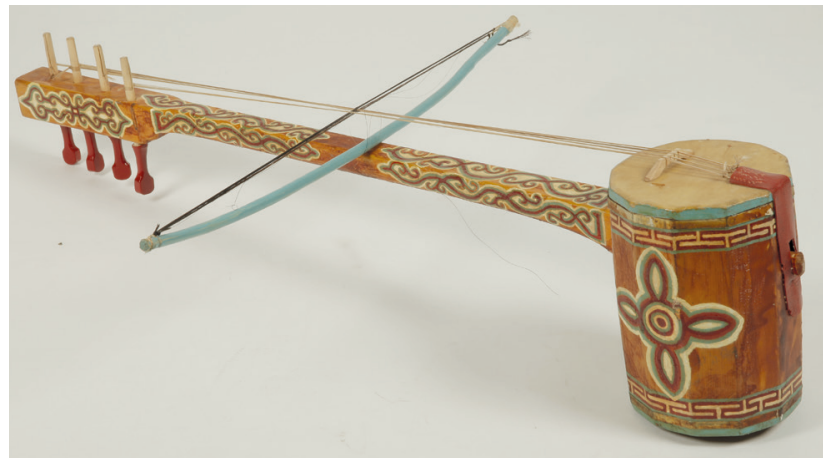

Fig. 12. Byzaanchy. Tuvinians. RME, inv. № 10064-68/ab

a) Instrument is spike box lute.

Body, 12-faced, assembled, glued of plates. Inside all joints glued by paper strips. Outside edges of body fastened by metal tapes. Back of body is open, face is tightened by leather, unbent and glued to body Neck, head, spike and bulge in body lower part cut out from uniform piece of wood Neck, fed through body at distance $4,0 \mathrm{~cm}$ from face body. Neck on face flat, from back round.

Tuning pegs holes with diameter of $0,7-1,0 \mathrm{~cm}$ drilled through, placed on head diagonally at equal distances from each other. Tuning pegs of slightly pointed shape with massive extended handles, inserted from back of instrument head. Tuning pegs supplied with longitudinal splits for fastening strings.

The tailpiece, strip of leatherette with split. Split, put on bulge from below, lower part of tailpiece glued to body. Four twisted ropes for strings, down to backside of leatherette strips. 
Instrument supplied with flat wooden bridge under strings with pit in the lower part, with angles strongly smoothed and four grooves under strings.

1 and 2 strings from white horsehair, 3 and 4 from white mixed with black and red hair. Strings are tied to ropes of tailpiece, fed through bridge and to splits of tuning pegs.

Instrument body decorated with geometrical and vegetative ornament, face and lateral sides of neck and head decorated with curvilinear ornament. Ornament painted red, white, and green. Tuning pegs handles painted red. Unbent part of leather membrane painted blue. Instrument body, neck, head covered with golden varnish.

Total length of instrument $-93,0 \mathrm{~cm}$

Length of body $-15,0 \mathrm{~cm}$, length of bulge $-1,5 \mathrm{~cm}$

Neck length with head $-76,5 \mathrm{~cm}$, length of head $-21,0 \mathrm{~cm}$

b) Bow of arch-shaped form. Rod of bow made of cleaned branch and covered blue.

Two grooves for fastening strings cut along edges of body for fastening ropes. Bunches of dark black and brown horsehair tied to them. To each couple of strings horsehair bunch tied. Long bunch fed through first and other strings. Second bunch fed through fourth and other strings.

Total length $-66,0 \mathrm{~cm}$

Rod $-66,5 \mathrm{~cm}$

Curve depth $-3,0 \mathrm{~cm}$

RME, inv. № 6957-16/ab.

Khuur. Mongols.

The first quarter of the $20^{\text {th }}$ century. Urga ${ }^{25}$, Mongolia. 1923.

Mongolian-Tibetan expedition by supervision of P. K. Kozlov.

Collector S. A. Kondratyev (fig. 13).

Wood, leather, horsehair, paint

a) Instrument represents spike box lute, trapezoid, smoothed top angles of body with rod of rectangular section transforming into long neck with head. Rod, neck and head cut out from a uniform piece of wood.

Body consists of frame made of rectangular plates locked and glued together. Bottom - plate $0,7 \mathrm{~cm}$ thick, glued overlap and pinned to body. Through round hole diameter of 12,6 cm cut out at bottom top where carved wooden socket with four semicircles forming five through resonator splits enclosed (fig. 14).

Face body cavity tightened overlap and glued. Leather stuck with nails along four angles of body. Spike bulges out, edges of bulging part smoothed. Tailpiece thong fed through two holes in bulge. Length of free parts of tailpiece $-20,0$ and 19,4 cm.

Neck is straight, flat on face, round from backside. Neck narrowed in middle. Head carved in form of heads of dragon and horse (fig. 15, 16).

Narrow split of peg box is cut out from back. At basis of head two through holes for strings going to face hewed. Face of peg box carved in form of dragon head with white horns, waving hair, animal forehead decoration, and open mouth.

25 Ikh-Huree, nowadays Ulaanbaatar. 


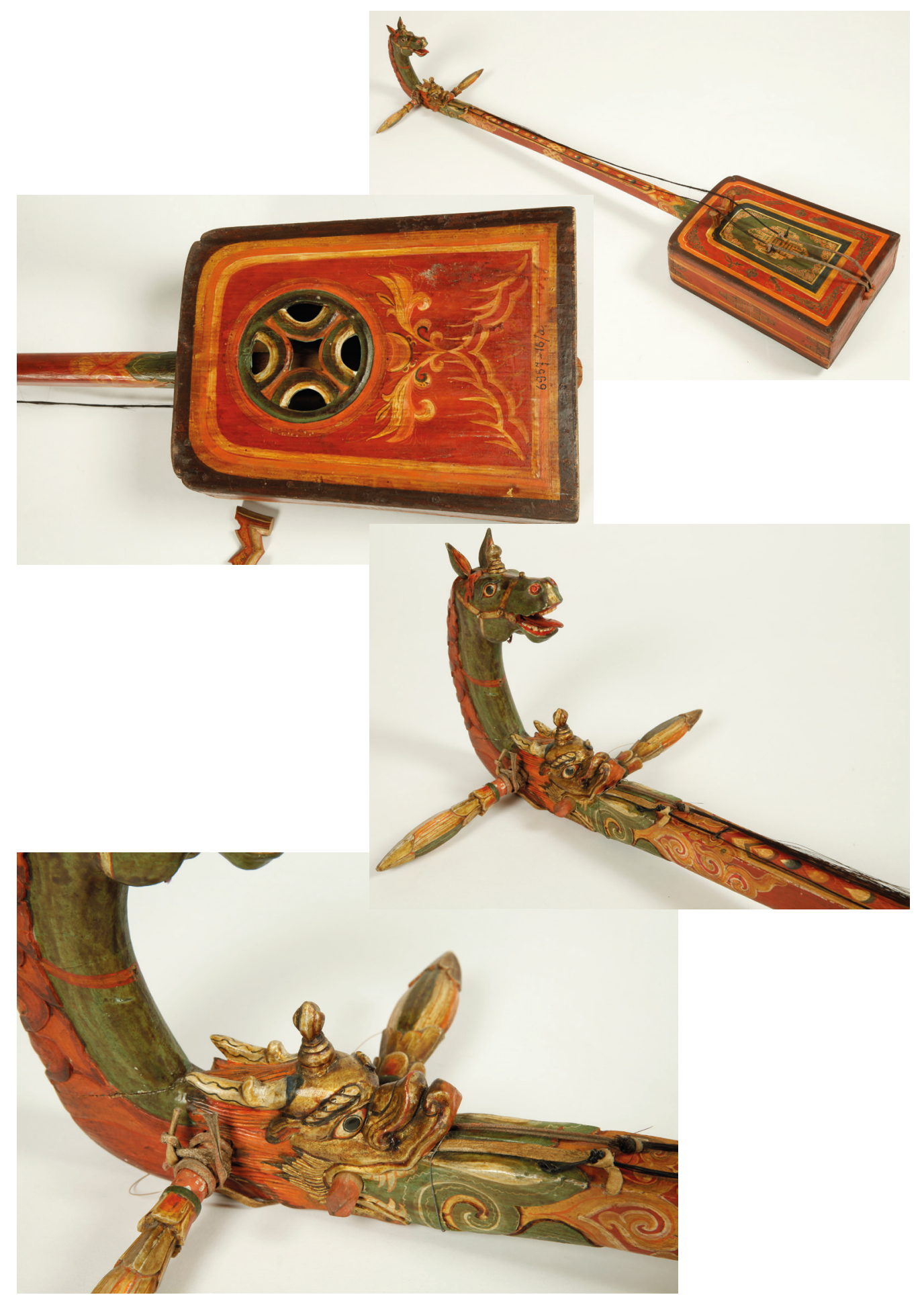

Fig. 13, 14, 15, 16. Khuur. Mongols. RME, inv. № 6957-16/ab 
Tuning pegs slightly pointed in shape. Through holes for fastening strings hewed in extended part of tuning pegs. Oval handles cut in shape of slightly flat bud.

Upper part of head carved in form of horse neck and head bent down with toothy mouth. Horse with harness and garnish. Carved image of ears, inserted into two square splits in upper part of head. At basis of carved image of ear, small through hole is made for movable fastening. Strengthened across metal rod to which carved image of horse tongue attached is deep in open mouth. Obviously, while playing the instrument these details (ears and tongue) came into motion. Head with carved images and tuning pegs painted green, red, black, white and gold.

M-shaped bridge, expanding upwards, and two recesses under strings. Carved in wood.

Instrument body, neck, bridge, neck decorated and painted red, orange, yellow, white, green, brown, and black. Ornament geometric and in vegetation.

Traces of inserted bridge from its top edge remained in upper part of leather membrane at distance of $5,7 \mathrm{~cm}$.

Bunch of horsehair, fed through bridge tied to ends of straps of tailpiece. Upper end of each string tied to leather thong and through it with tuning pegs.

Total length $-114,0 \mathrm{~cm}$,

Length of body $-33,5 \mathrm{~cm}$, length of bulge $-1,2 \mathrm{~cm}$

Length of neck and head $-79,3 \mathrm{~cm}$ (length of neck $-63,0 \mathrm{~cm}$, length of head with upper bulge $-16,3 \mathrm{~cm}$ )

Width of body $-26,4 \mathrm{~cm}-22,6 \mathrm{~cm}$

Hight of body $-9,0 \mathrm{~cm}$

RME, inv. № 8761-8415/ab.

Igil (“ihil”). Tuvinians (Todzhinets).

The first quarter of the $20^{\text {th }}$ century. Settlement on the river Iy, 5 versts from the settlement of Petrov, Tannu-Tuva ${ }^{26} .1926$.

Tannu-Tuvinian complex ethnography-anthropological expedition supervised by of prof. V.V.Bunak. Collector M. G. Levin. Acquired from Tandgik Kol-Sumo (fig. 17).

Wood, leather, tendinous rope, horse hair

a) Instrument is spike box lute. Body "hardga" 27 (haarzhak, in translation from the Tuvinian - box [see: 11, p. 225]) made of wooden plates is tightened with leather. Leather is stitched with tendinous threads on the ends.

Spike with bulge and neck with head "syby" (syvy, in translation from the Tuvinian grip) are cut from single solid piece of wood. Spike is fed through body, pointed bulge of triangle shape. Bowed twisted tendinous thread is fastened to bulge Bunch of horsehair is tied to it. Neck of square section with longitudinal pit from the backside. Head is square. Tuning peg is hewed from backside. Nut is carved on the face $1,0 \mathrm{~cm}$ below tuning peg box. Tuning pegs of "hula" (kulak, in translation from the Tuvinian - an ear) are inserted sideways. Fragment of a tuning peg has remained. Two holes for strings "hyl" (in translation from the Tuvinian - hair, string) are drilled in the lower part of tuning peg box on the

${ }^{26}$ Now this territory belongs to the Iysky Sumon of the Todzhinsky kozhuun of the Republic of Tyva.

27 Ethnic terms are given in the transcription of the collector (see above). 


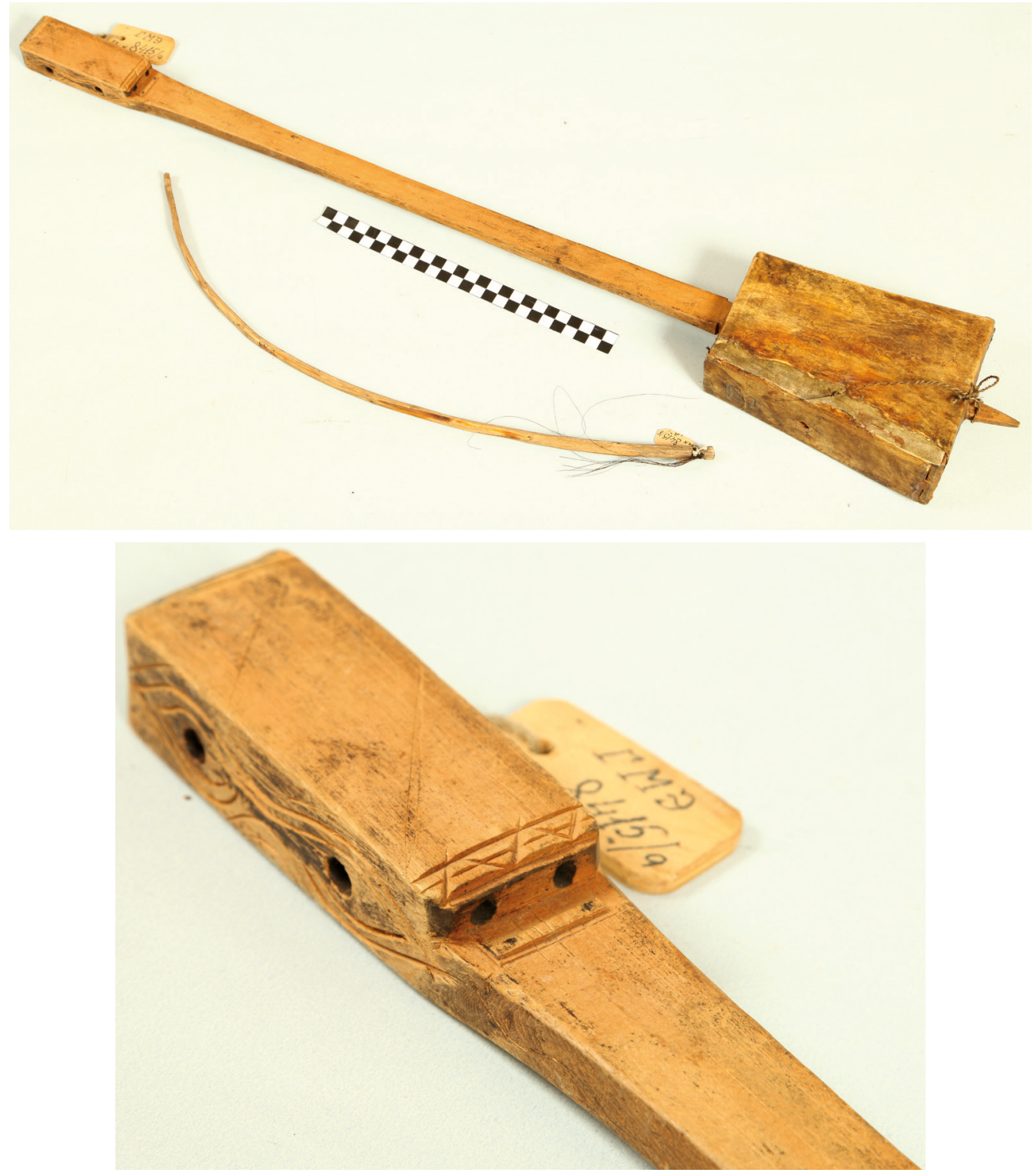

Fig. 17, 18. Igil (“ihil”). Tuvinians (Todzhinets). RME, inv. № 8761-8415/ab

face. The head is decorated with carved ornament: on the sides - stylized floral ornament on the front and back sides - geometric (fig. 18).

Total length $-88,5 \mathrm{~cm}$

Length of body $-18,0 \mathrm{~cm}$

Width of body $-14,0-10,5 \mathrm{~cm}$

Height of body $-5,6 \mathrm{~cm}$ 


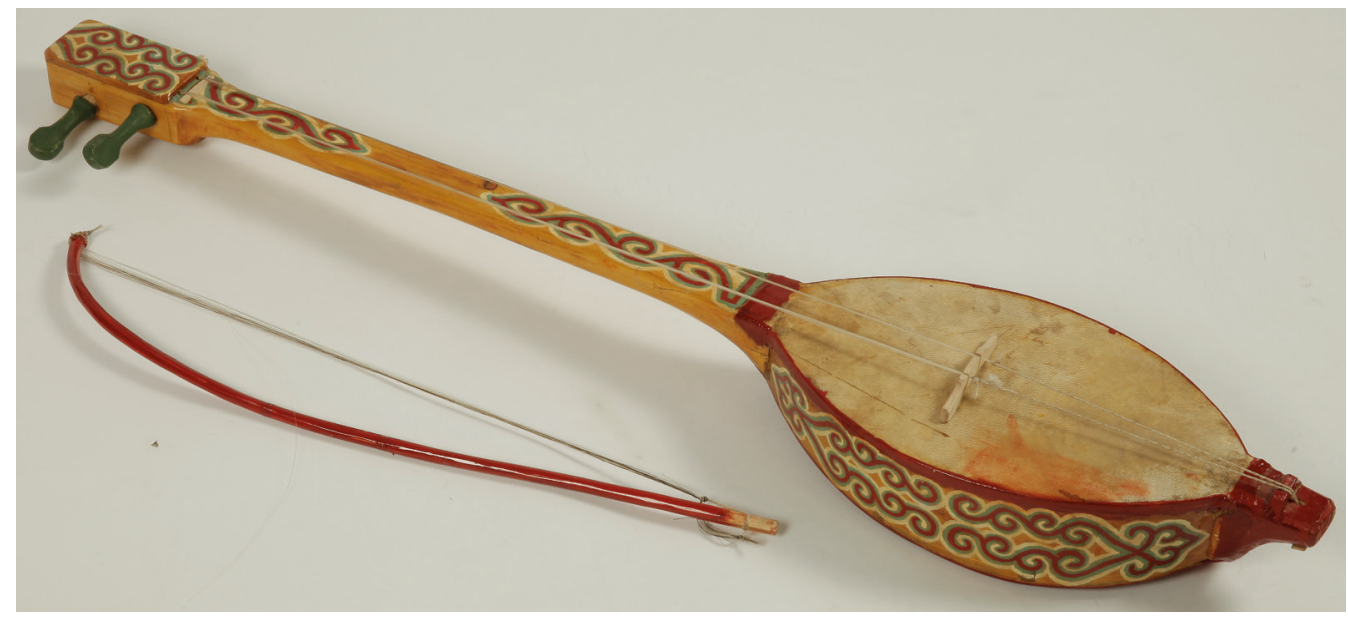

Fig. 19. Igil. Tuvinians. RME, inv. № 10064-69/ab

b) Bow "chadzh" (chazhak, in translation from the Tuvinian - bow) of arch-shaped form, rod is well-cut curved branch, Some portion of black horsehair has remained. Pits for fastening hair are cut on the edge of rod.

Total length $-51,0 \mathrm{~cm}$

Rod $-57,0 \mathrm{~cm}$

Curve depth $-8,5 \mathrm{~cm}$

RME, inv. № 10064-69/ab.

Igil. Tuvinians.

1979. State farm Kara-Khol, Bai-Tayginsky area, the Tuva ASSR.

Collector - N. G. Aloyeva. Maker - B. L. Kuzhuget (fig. 19).

Wood, leather, horse hair, twisted nylon rope, oil paint

a) Instrument is composite. Body flat of oval shape Bulge, narrowed from top to bottom in the lower part of body.

Lateral sides of body have different width (see body height), due to it bottom of body is of convex form. Two cross bars of square section inserted sidewalls fix bottom. Goat leather covers face body cavity.

Neck and tuning peg box cut out from uniform piece of wood. Fragment attached to back basis of neck (ordinary restoration?). Instrument bottom and face of head are made of separate plates.

Through hole for tailpiece - in lower part of bulge. Tailpiece from a twisted double rope is fed by loop through back of bulge and fixed by splinter. Length of loose ends of tailpiece $20,5 \mathrm{~cm}$. Additional support for tailpiece on face bulge is cut out.

Neck on face flat, from back round. Nut glued to basis of head, flat splinter $3,7 \mathrm{~cm}$ long, $0,5-0,6 \mathrm{~cm}$ wide, $2,5 \mathrm{~cm}$ high.

Square head with truncated angles. Tuning peg box hollowed through. Face tuning peg box glued with plate, two holes for strings drilled in lower part. Tuning peg holes 
drilled from lateral side of tuning peg box. Tuning pegs slightly pointed with massive extended handles.

Instrument supplied with flat wooden bridge under strings with pit in the lower part and two grooves under strings at top. Strings of white horsehair, other of white and several black hairs. Strings tied to the tailpiece, fed through bridge and nut, then passed through head holes, through peg's split, and bowed.

Lateral walls of instrument, face of neck and head decorated with curve lined ornament painted white, green and red. Bottom and bulge of body, unbent edge of leather painted red. Handles of tuning peg painted green. Instrument body with bulge, neck with head varnished.

Total length - 96,0 cm

Body length with bulge $-36,5 \mathrm{~cm}$ (length of bulge $-5,5 \mathrm{~cm}$ )

Neck length with head $-59,5 \mathrm{~cm}$

Width of body $-17,5 \mathrm{~cm}$

Height of body $-6,2-8,0-6,7 \mathrm{~cm}$

b) Bow

Bow rod - bent cut branch. Superficial grooves for twisted rope are cut on ends of rod. Bunch of white and black horsehair tied to rope. Rod is drawn by thin thread in two places (ordinary restoration). Painted red.

Length $-55,0 \mathrm{~cm}$

Length of rod $-59,2 \mathrm{~cm}$

Maximum depth of curve $-8,0 \mathrm{~cm}$

RME, inv. № 9915-72 ab.

Kytiya Khyryppa ${ }^{28}$. Yakuts.

1978. Maker - [I. M.] Neustroev. Collector - L. G. Lelchuk (fig. 20, 21).

Wood, metal, fishing line, cotton thread, lacquer, paint

a) Instrument of prefabricated body, cut neck with head and overlapped fingerboard. Body resembles hourglass. Body made of combined frame and overlapped decks glued together. Frame assembled of three parts: two wide with rounded edges and narrow straight medium (intercept). Decks convex hewed out of solid piece of wood and glued to frame overlapping. Two symmetric resonator holes cut in upper deck. Rectangular wooden plate glued in the middle of upper deck (ordinary restoration?). Two pair of soundposts cut in lower and top parts of upper deck. Visible part of soundposts is of round section, inside body they are cut flat.

Narrow thin curved metal plate, inserted in one of resonator holes like strut. One end located next to resonator hole (probably to create special sound effect). Neck with head and carved garnish-cut from single piece of wood. Slightly convex fingerboard connected with spike glued to neck.

${ }^{28}$ In translation from the Yakut - bowl-violin [see: 12]. Description of the instrument given by the collector in the registration card States: "the housing has the form of two tapered vessels - bowls (kytiya), connected by a hollow rounded jumper". 

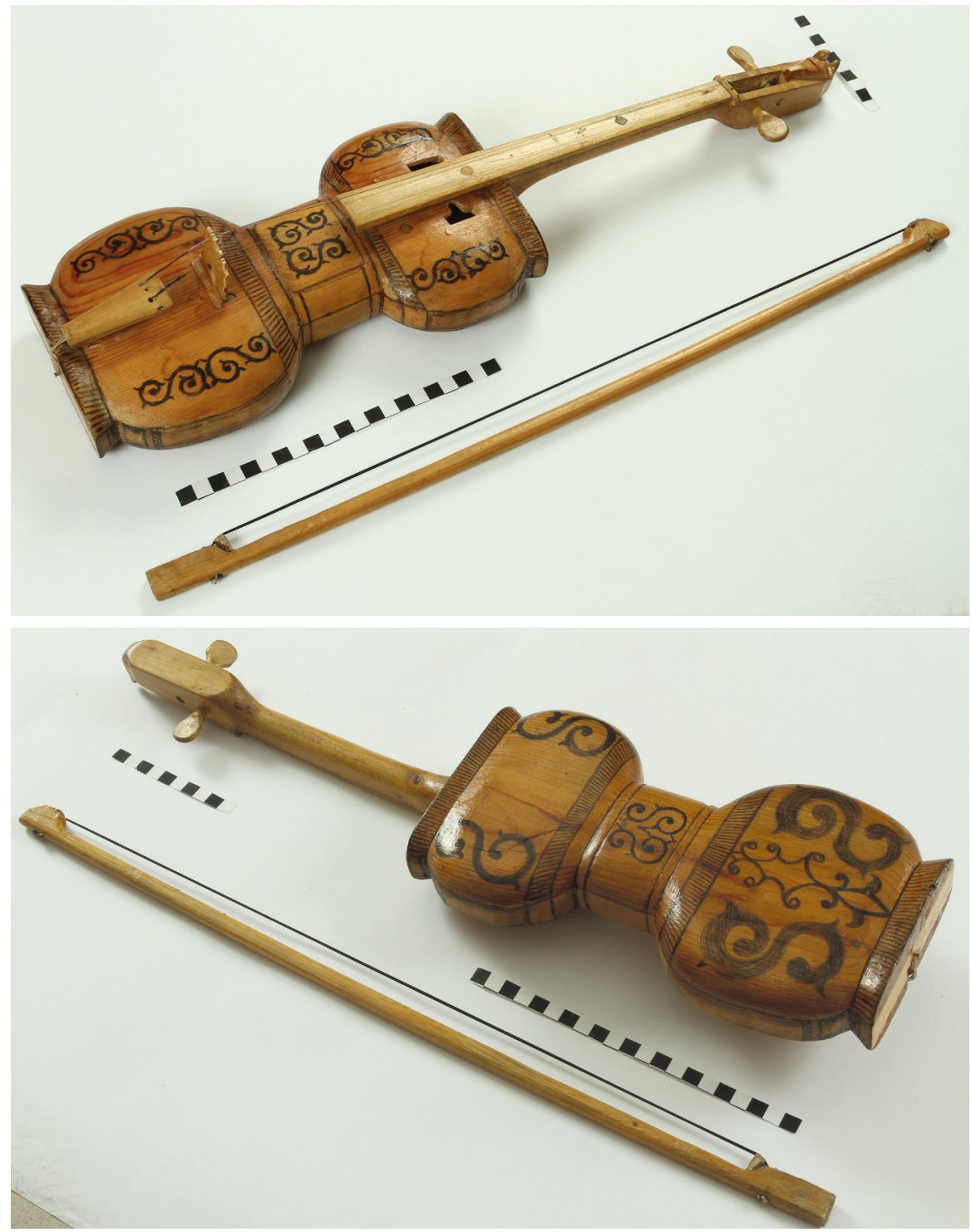

Fig. 20, 21. Kytiya Khyryppa. Yakuts. RME, inv. № 9915-72/ab

Nut cut and glued to basis of head. Peg box cut on face. Two tuning pegs of slightly conic shape with spade-like handles inserted on both sides of tuning peg box.

Upper part of head carved in form of horse's head.

At bottom of body in middle of hammered nail, fishing line attached to tailpiece. At top of tailpiece three holes cut, two used for strings. Two metal strings tied to tailpiece, fed through bridge and wound around tuning pegs.

Bridge - thin plate with arch-shaped recess in the lower part and wavy edges on lateral sides and at top. Thin plate glued to basis of bridge (ordinary restoration?) probably in order to increase height of bridge. 
Instrument's decks decorated richly with stylized floral and geometric ornaments fulfilled in burning technique. Instrument varnished.

Total length $-59,0 \mathrm{~cm}$

Body length $-30,4 \mathrm{~cm}$

Width of body: at top $-15,8 \mathrm{~cm}$, in middle $-8,7 \mathrm{~cm}$, at bottom $-16,0 \mathrm{~cm}$

Body height $-4,5 \mathrm{~cm}$, including frame height $-2,3-2,5 \mathrm{~cm}$

Neck length with head $-28,5 \mathrm{~cm}$ (including head length $10,2 \mathrm{~cm}$, neck length $18,3 \mathrm{~cm}$ )

Length of fingerboard $-29,4 \mathrm{~cm}$

b) bow (Yakut. chaachar)

Length of rod $-58,0 \mathrm{~cm}$, including length of handle $5,0 \mathrm{~cm}$ and thickening at top $-3.0 \mathrm{~cm}$. The width of handle $-2,0 \mathrm{~cm}$

Thickening at top $-2,0 \mathrm{~cm}$

Diameter of rod $-1,0 \mathrm{~cm}$

The bowed traditions of the Siberian peoples represent one of the most original areas of instrumentalism, which gives the key to understanding the history and culture of ethnic groups. Museum collections, in which samples of musical instruments of the past centuries are preserved, are the most valuable evidences of instrumental traditions of the past. Many of these instances reflect the methods of making instruments that are currently lost or are fading. The study of stringed musical instruments of the Turkic-Mongol peoples of Siberia from the collection of the RME - records of the past - significantly expands the idea of modern ethno-organology about the subject material and spiritual culture.

As there sult of study of bow instruments the following features are identified:

1. Two main types (according to E. Hornbostel and K. Sachs) necked lute (321.32): necked bowl lute (321.321: igil, yykh, ikili-topshur), necked box lute (321.322: igil, kytiya khyryppa); spike lute (321.31): spike box lutes (321.312: khuur, igil), spike tube lutes (321.313: byzaanchy);

2. The shape of the hull spike lutes: a) tubular (byzaanchy), b) box shaped; the latter of two types: with a transversely elongated resonator (byzaanchy), with a longitudinal extended resonator (huur, igil);

3. Types of spike lutes body: a) face is tightened with leather (byzaanchy, igil), b) covered with leather on both sides (igil); c) face is covered with leather, back side of a wooden plug (byzaanchy) or a wooden board (khuur);

4. Upper deck material: a) leather (igil, yykh, byzaanchy, khuur, ikili-topshur); b) wood (kytiya khyryppa);

5. Neck shape: long (igil, byzaanchy, yykh, khuur, kytiya khyryppa), medium length $($ yykh);

6. The shape of the head: pegged box (igil, yykh, khuur, ikili-topshur, kytiya khyryp$p a)$ and without pegged box (byzaanchy), the latter type: head is not expressed, neck is smoothly extended (byzaanchy); 
7. Types of peg boxes: hollowed out from the bottom (igil, yykh, khuur, ikili-topshur); hollowed out on top (kytiya khyryppa);

8. An arrangement of pegs - side (igil, yykh, khuur, kytiya khyryppa, ikili-topshur), longitudinal (byzaanchy);

9. Types of pegs - a) with a hole (byzaanchy, khuur), b) with cross-section (igil, byzaanchy, yykh);

10. Methods of fastening the sides of the membrane: a) leather harnesses or tendon rope, tightening the leather membrane on the back side of the resonator (igil), b) using wooden (metal) carnations (yykh, khuur, ikili-topshur), c) combined, combining the first two methods (khuur); d) glued (byzaanchy, yykh);

11. Types of tailpiece: a) leather straps or tendon rope fed through into the hole in the $\operatorname{rod}($ igil, $y y k h), \mathrm{b}$ ) attached to the rod by a piece of leatherette, which is tied to the twisted rope (byzaanchy), c) tendon rope, the ends of which are tied to leather string support (igil); d) in the form of a wooden curved plate (kytiya khyryppa);

12. Methods of fastening the tailpiece: a) tailpiece-strap (leather, tendon rope) tied to the rod in the lower part of the body (igil, $y y k h), b$ ) tailpiece in the form of a piece of leatherette attached to the bode bugle (byzaanchy); c) leather strip is put on the rod in the lower part of the body (ikili-topshur); d) tailpiece in the form of a bent wooden plate is attached to the carnation in the lower part of the instrument by means of a fishing line (kytiya khyryppa);

13. Methods of attachment of the strings in the lower part: a) to the leather straps, to tendinous or twisted ropes (igil, khuur, yykh);

14. Forms of rods in the lower part of the body for fastening of tailpiece: round (byzaanchy, khuur, yykh), pointed (igil), triangular (igil), pentagonal with the rounded edges (igil);

15. The presence or absence of strap (for hanging the instrument) attached to or fed through the hole in the neck;

16. Types of resonator holes and their location: a) in the leather membrane stretched on the back of the instrument (igil, khuur);

17. The material strings - a bundle of untwisted horsehair (igil, byzaanchy, yykh); fishing line (ikili-topshur); metal (kytiya khyryppa);

18. Ways of ornament and decoration of instruments and their components: a) tradition of making carved heads: a horsehead and a dragon (khuur, kytiya khyryppa), b) carved details of pegs holes (byzaanchy); c) painting of the body, neck, head in different colors (igil, byzaanchy, khuur), d) cutting or drawing of an ornament on a neck and a head (igil, khuur), burning ornament on the upper and lower decks (kytiya khyryppa).

The results of this work should be the first step towards creation of a systematic catalogue of bow instruments in the collection of the Russian Ethnographic Museum, an approach to the creation of unified catalogue of bow instruments of the peoples of Eurasia in the collections of Russian and foreign museums. The publication of a complete systematic catalogue of bowed instruments of Eurasia, with illustrations of musical instruments, no doubt, will be in demand of further research, as well as of scientific-practical and educational work. 


\section{References}

1. Aleksandrova, Liudmila, et al., comp. Rossiiskii etnograficheskii muzei 1902-2002. St. Petersburg: Slaviia, 2001. (In Russian)

2. Kon, Feliks. Za piat'desiat let. Sobranie sochinenii. 3 vols. Moscow: Izd-vo Vsesoiuz. o-va politkatorzhan i ssyl'no-poselentsev, 1934, vol. 3. (In Russian)

3. Chernysheva, Vera, ed. and comp. Illiustrirovannaia etnografiia Tuvy. Iz sobraniia Minusinskogo regional'nogo kraevedcheskogo muzeia im. N. M. Mart'ianova. Abakan: OOO "Kooperativ 'Zhurnalist", 2009. (In Russian)

4. Ivanov, Vasilii. Narody Sibiri v trudakh F. Ia. Kona. Edited by Rudol'f Its. Novosibirsk: Nauka. Sibirskoe otdelenie, 1985. (In Russian)

5. Vainshtein, Sev'ian. "Feliks Iakovlevich Kon kak etnograf”. In Institut etnografii im. N. N. MiklukhoMaklaia. Ocherki istorii russkoi etnografii, fol'kloristki i antropologii, edited by Vera Sokolova, 196-220. Moscow: Nauka, 1965, iss. 3. (In Russian)

6. Sankt-Peterburgskii gosudarstvennyi muzei teatral'nogo i muzykal'nogo iskusstva. Kollektsiia muzykal'nykh instrumentov. Nauchnyi katalog, compiled by Vladimir Koshelev, edited by Nina Zakhar'ina. St. Petersburg: SPb GBUK SPbGMTiMI, 2016, vol. 2. (In Russian)

7. Kozlov, Petr. Puteshestvie v Mongoliiu 1923-1927 gg. Prepared by Elizaveta Kozlova, edited by Eduard Murzaev. Moscow: Geografgiz, 1949. (In Russian)

8. Kondrat'ev, Sergei. "O rabotakh po izucheniiu mongol'skoi muzyki v oktiabre-dekabre 1923 g. v Urge". Izvestiia Russkogo geograficheskogo obshchestva [Regional Research of Russia] 56, no. 1 (1924): 174-6. (In Russian)

9. Sheikin, Iurii. Istoriia muzykal'noi kul'tury narodov Sibiri. Moscow: Vostochnaia literatura, 2002. (In Russian)

10. Khornbostel', Erikh fon, and Kurt Zaks. "Sistematika muzykal'nykh instrumentov". In Narodnye muzykal'nye instrumenty i instrumental'naia muzyka. 2 parts, edited by Evgenii Gippius, 227-61. Moscow: Sovetskii kompozitor, 1987, pt. 1. (In Russian)

11. Suzukei Valentina. "Igil". In Muzykal'nye instrumenty. Entsiklopediia, compiled by Angelina Alpatova et al., edited by Margarita Esipova: 225-6. Moscow: Deka-VS, 2008. (In Russian)

12. D’iakonova, Varvara. "Smychkovaia liutnia - kyryympa (konstruktivnye formy i ispolnitel'skie priemy)". In Kyryympa: istoriia i perspektivy razvitiia, compiled by Igor' Vorob’ev and Varvara D'iakonova, 25-71. Moscow: Kompozitor, 2018. (In Russian)

\section{Sources}

I. Archive of Russian Museum of Ethnography. Stock 5. Inventory 4. Record 282. (In Russian)

II. Archive of Russian Museum of Ethnography. Stock 1. Inventory 2. Record 341. (In Russian)

III. Archive of Russian Museum of Ethnography. Stock 5. Inventory 2. Record 95. (In Russian)

IV. Archive of Russian Museum of Ethnography. Stock 5. Inventory 4. Record 10; Record 11. (In Russian)

V. Archive of Russian Museum of Ethnography. Stock 5. Inventory 4. Record 311. (In Russian)

VI. Archive of Russian Museum of Ethnography. Stock 2. Inventory 1. Record 576. (In Russian)

VII. Archive of Russian Museum of Ethnography. Stock 2. Inventory 1. Record 487. (In Russian)

VIII. Archive of Russian Museum of Ethnography. Stock 2. Inventory 1. Record 595. (In Russian)

Received: March 16, 2018

Accepted: August 30, 2018

Author's information:

Dinara A. Bulatova - PhD; dinara.bulatova@mail.ru

Aishat A. Gadjieva — aishatg@mail.ru 


\title{
Смычковые инструменты тюрко-монгольских народов Сибири из коллекции Российского этнографического музея
}

\author{
Д. А. Булатова ${ }^{1}$, А. А. Гаджиева ${ }^{2}$ \\ ${ }^{1}$ Российский институт истории искусств, \\ Российская Федерация, 190000, Санкт-Петербург, Исаакиевская пл., 5 \\ 2 Российский этнографический музей, \\ Российская Федерация, 191186, Санкт-Петербург, Инженерная ул., 4/1
}

Для цитирования: Bulatova, Dinara, Gadjieva Aishat. "Bowed Instruments of the Turkic-Mongol Peoples of Siberia from the Collection of the Russian Museum of Ethnography". Вестник Санкт-Петербургского университета. Искусствоведение 8, no. 4 (2018): 540-66. https://doi. org/10.21638/spbu15.2018.401

Статья посвящена изучению одного из наиболее репрезентативных в России собраний традиционных музыкальных инструментов - коллекции Российского этнографического музея. Внимание авторов обращено к смычковым хордофонам тюрко-монгольских народов Сибири. Особую историко-культурную ценность представляют наиболее ранние образцы, собранные в первой половине XX века: два игила и бызаанчы тувинцев (сойотов), сбор Ф.Я. Кона (1902 г.); хур монголов, сбор С. А. Кондратьева (1923 г.); игил тувинцев (тоджинцев), сбор М. Г. Левина (1926 г.); ыых хакасов, сбор Л.Н. Терентьевой (1939 г.). Показательны и более поздние образцы, относящиеся ко второй половине XX - началу XXI века: игил и бызаанчы тувинцев, сбор Н. Г. Алоевой, мастер Б. Л.Кужугет (1979 г.), икили-топшур алтайцев, сбор С.В. Романовой и М.Н.Кочуковой (2006 г.), кытыйа кырыппа, сбор Л.Г. Лельчук, мастер [И. М.] Неустроев (1978 г.). Приводится история комплектования собрания смычковых хордофонов тюрко-монгольских народов Сибири, дается подробное эргоморфологическое описание инструментов, репрезентирующих культуру тувинцев, алтайцев, хакасов, монголов, якутов. Описываемые хордофоны относятся к следующим органологическим типам (согласно систематике Э. Хорнбостеля и К.Закса): шейковая лютня (321.32): чашечная шейковая лютня (321.321: игил, ыых, икили-топшур), коробчато-шейковая лютня (321.322: кытыйа кырыппа); пиколютня (321.31): коробчатая пиколютня (321.312: хур, бызаанчы, игил), трубчатая пиколютня (321.313: бызаанчы). Делаются выводы об эргоморфологических особенностях инструментов: типах резонатора, размерах шейки, видах головок и колковых коробок, расположении колков, разновидностях струнодержателей, материале дек и способах их крепления, видах резонаторных отверстий и месте их расположения, материале струн, особенностях украшения и орнаментирования инструментов и пр.

Ключевые слова: смычковые инструменты, хордофоны, тюрко-монгольские народы Сибири, игил, бызаанчы, ыых, хур, икили-топшур, кытыйа кырыппа.

Контактная информация:

Булатова Динара Айдаровна - канд. искусствоведения; dinara.bulatova@mail.ru Гаджиева Айшат Ахмедовна - aishatg@mail.ru 